\title{
PERAN GURU DALAM PEMBELAJARAN SENI BUDAYA KELAS IV DI SDI MANUNAI MAUMERE
}

\author{
Benyamin Regi \\ Universitas Nusa Nipa, Jln. Kesehatan No.03 Maumere, regibenyamin@ gmail.com
}

Diterima 29 Juni 2020, disetujui 05 Oktober 2020, diterbitkan 30 Oktober 2020

Pengutipan: Regi, B (2020). Peran Guru Dalam Pembelajaran Seni Budaya Kelas IV di SDI Manunai Maumere. Gema Wiralodra, Vol 11, No 2, Hal 190-204, Oktober 2020

\begin{abstract}
ABSTRAK
Penelitian ini bertujuan untuk mendeskripsikan peran guru dalam pembelajaran seni budaya melukis dengan menggunakan media di SDI Manunai Maumere. Penelitian ini menggunakan metode deskriptif melalui pendekatan kualitatif. Sumber data dalam penelitian ini adalah guru seni budaya dan siswa yang mengikuti pembelajran seni budaya di kelas IV SDI Manunai Maumere yang berjumlah 30 siswa. Teknik pada pengumpulan data dilakukan pada penelitian ini adalah observasi, wawancara, dokumentasi dan angket, analisis data menggunakan deskriptif. Peran guru yang terdapat pada proses pembelajaran di SDI Manunai Maumere memperlihatkan sesungguhnya guru bias mengelementasikan 7 dari 9 peran guru yang dijalankan pada proses belajar mengajar, yaitu guru sebagai perencana proses belajar dan mengajar, guru sebgai pengatur proses belajar, guru sebagai pembimbing dalam proses belajar, guru sebagai penilai, guru sebagai tempat konsultasi kepada siswa, guru harus menggunakan kurikulum yang berbasis lingkungan, tugas serta tanggung jawab guru, dan syarat guru yang baik dan berhasil.
\end{abstract}

Kata kunci: Peran Guru, Pembelajaran, Seni Budaya

\begin{abstract}
This study aims to describe the role of teachers in learning cultural arts using the media at SDI Manunai Maumere. This study uses a descriptive method through a qualitative approach. Sources of data in this study were cultural arts teachers and students who took part in the arts and culture learning in grade IV SDI Manunai Maumere that was designed by 30 students. Techniques for the data carried out in this study were observation, interviews, documentation and questionnaires, data analysis using descriptive. The teacher's role in the learning process at SDI Manunai Maumere, which is actually a teacher, can implement seven of the nine teacher roles that are carried out in the teaching and learning process. Namely the teacher as a learning and teaching process planner, the teacher as a regulator of the learning process, the teacher as a guide in the learning process, the teacher as an assessor, the teacher as a place for consultation with students. The teacher must use an environment-based curriculum, the duties and responsibilities of the teacher, and the requirements for a good and successful teacher.
\end{abstract}

Keyword: The Role of Teacher, Learning, Arts and Culture

\section{PENDAHULUAN}

Pendidikan formal merupakan pendidikan yang dilakukan berdasarkan tuntutan kurikulum yang ada. Dari segi administrasi, gedung sekolah dan sampai mata pelajaran yang diampu oleh masing-masing guru. Pendidikan dan pengajaran 
suatu hal yang tidak bias dipisahkan karena pengajaran merupakan bagian dari pada pendidikan. Tujuan dari pendidikan dan pembelajaran selain mencerdasakan juga untuk mendidikan anak dari tiga aspek yakni kognitif, afektif dan psikomotorik. Psikomotorik atau keterampilan yang dimiliki oleh anak merupakan kemampuan siswa dalam lekaukan sesuatu dalam proses belajar. Prestasi yang tinggi di dalam salah satu mata pelajaran mencerminkan bakat yang unggul dalam pada bidang tersebut. Kemudian diaplikasikan dalam dunia pendidikan secara formal di sekolah.

Keterampilan atau ranah psikomotor adalah ranah yang berkaitan dengan bakat pada siswa atau kemampuan bertindak setelah seseorang menerima pengalaman belajar pada mata pelajaran tertentu. Hasil belajar psikomotor ini sebenarnya merupakan kelanjutan dari hasil belajar kognitif (memahami sesuatu) dan dan hasil belajar afektif (yang baru tampak dalam bentuk kecenderungankecenderungan berperilaku). Ranah psikomotor atau keterampilan pada siswa ini berhubungan dengan aktivitas fisik. Pendidikan merupakan suatu usaha yang dilakukan oleh manusia agar dapat mengembangkan potensi yang dimilikinya melalui proses pembelajaran maupun cara lain yang dikenal dan diakui masyarakat. Setiap manusia memiliki hak yang sama untuk mendapatkan layanan pendidikan yang layak. Melalui pendidikan, manusia dapat memperoleh pengalaman yang bermakna bagi dirinya, masyarakat maupun pembangunan negara.

Pembelajaran diartikan sebagai suatu proses untuk menciptakan atau membuat kondisi yang kondusif agar terjadi interaksi komunikasi belajar mengajar anatara guru, peserta didik, komponen pembelajaran lainnya untuk mencapai tujuan pembelajaran. pembelajaran merupakan suatu sistem, yang terdiri atas berbagai komponen yang saling berhubungan satu dengan yang lain. Komponen tersebut meliputi: tujuan, materi, metode, dan evaluasi. Keempat komponen tersebut harus diperhatikan oleh guru dalam memilih dan menetukan media, metode, strategi, dan pendekatan apa yang akan digunakan dalam kegiatan pembelajaran (Hosnan, 2014: 18) berdasarkan uraian tersebut, tujuan pembelajaran adalah mempengaruhi peserta didik agat terjadi proses belajar. 
Guru merupakan jabatan atau profesi yang merupakan keahlian khusus sebagai guru, pekerjaan ini tidak bisa di lakukan oleh sembarang orang tanpa memiliki keahlian khusus sebagai mana di kemukakan oleh Usman (2013: 23). Untuk menjadi guru diperlukan syarat syarat khusus dan harus menguasai bagaimana pendidikasn dan pengajaran dengan berbagai ilmu pengetahuannya yang perlu dibina dan dikembangkan melalui masa pendidikan tertentu atau pendidiksn prajabatan. Peran guru dalam pembelajaran tatap muka yang dikemukakan oleh Moon dalam (Uno, 2012:34), untuk merancang proses pembelajaran, mengelola, tempat konsultasi dan sebagai pelaksana kurikulum. Seni merupakan proses yang melibatkan kemampuan psikomotik atau keterampilan yang ada pada diri anak tersebut (Sumanto, 2006: 21). Pembelajaran seni budaya berisikan kajian rasa lebih dari pada kajian pikir. Dominasi kajian rasa ini menunjukan karakteristik yang tidak dimiliki oleh mata pelajaran lain. Karena itu pembelajaran seni budaya dapat dipandang sebagai faktor pelengkap dalam seluruh proses pendidikan, sehingga membuat lebih utuhnya setiap peserta didik sebagai individu.

Berdasarkan hasil observasi yang dilakukan di SDI (Sekolah Dasar Inpres) Manunai Maumere bahwa sekolah ini merupakan salah satu sekolah yang dulunya menerapkan pembelajaran seni budaya yang terdiri dari seni musik dan seni tari. Sekolah ini juga memiliki keunggulan di bidang prestasi. Dengan menjuarai lomba paduan suara (lagu Natal) dan lomba menari tarian tradisional (Tarian Hegong Kreasi) antar sekolah. Seiring berjalannya waktu kegiatan ekstrakurikuler seni musik dan seni tari tidak dijalankan lagi seperti biasanya karena kurangnya motivasi yang diberikan oleh guru sehingga siswa di sekolah ini kurang tertarik untuk kegiatan-kegiatan ekstrakurikuler seperti yang dijelaskan di atas. Hasil penelitian Pamungkas dkk (2017) menyatakan peran guru dalam pembelajaran seni tari di SMA N 1 Seputih Agung Lampung Tengah menunjukkan bahwa guru dapat menjalankan 10 peran dari 13 peran yang harus dijalankan dalam pembelajaran seni tari, yaitu guru sebagai korektor, guru sebagai informator, guru sebagai organisator, guru sebagai motivator, guru sebagai fasilitator, guru sebagai pembimbing, guru sebagai pengelola kelas, guru sebagai 
supervisior, guru sebagai evaluator, 3 peran yang belum dijalankan yaitu, guru sebagai mediator, guru sebagai inisiator, guru sebagai inspirator.

Pusparini (2016) menyatakan dari lima indikator peran guru, indikator guru sebagai demonstrator, pengelola kelas dan mediator berada pada kategori tinggi. Indikator lain yaitu guru sebagai fasilitator dan evaluator berada pada kategori sedang. Oleh karena itu, diharapkan para guru untuk lebih menambah wawasannya mengenai musik, baik teori maupun praktik, sehingga guru dapat melaksanakan perannya dalam pembelajaran seni musik secara optimal. Soehardjo (2012:4) dalam proses pembelajaran peran guru yang dimainkan oleh seni sangat signifikan, yaitu untuk mempersiapkan keterampilan dalam menunjang kegiatan kreasi dan apresiasi peserta didik. Mata pelajaran seni budaya diberikan di sekolah karena mempunyai manfaat, terhadap kebutuhan peserta didik. pemberian pengalaman yang baik dalam kegiatan berekspresi/kreasi melalui pendekatan belajar seni. Dalam pembelajaran seni budaya aspek seni budaya tidak di bahas secara tersendiri tetapi terintegrasi dengan seni.

Dari uraian diatas maka dapat disimpulkan bahwa pembelajaran seni budaya di sekolah dasar sangat penting terhadap perkembangan mental maupun fisik peserta didik. Bahkan, dengan pembelajaran seni budaya peserta didik dapat terbentuk ke arah yang lebih baik karena pembelajaran seni budaya dapat mengenalakan nilai-nilai dan norma-norma yang ada dalam masyarakat kepada peserta didik.

\section{METODE PENELITIAN}

Penelitian ini merupakan penelitian deskriptif kuantitatif dengan menggunakan metode survei.

\section{Teknik Pengumpulan Data}

Teknik pegumpulan data merupakan hal yang harus dilakukan oleh seorang peneliti untuk mendapatkan data. Tanpa mengatahui cara pengumpulan data, maka seorang peneliti tidak bias mendapatkan data (Sugiyono, 2015). Dalam penelitian kualitatif, pengumpulan data dilakukan secara ilmiah baik dengan wawancara, observasi dan dokumentasi (Sugiyono, 2015:46). Observasi merupakan salah satu teknik untuk mengumpulkan data pada saat melakukan penelitian (Sugiyono, 2015:33). Jenis observasi yang dilakukan pada penelitian ini 
yaitu observasi partisipan yaitu peneliti ikut terlibat langsung dalam kegiatan pembelajaran yang dilakukan di dalam kelas. Pengumpulan data secara observasi dengan melakukan pengamatan secara langsung di tempat penelitian yaitu SDI Manunai Maumere. Pengamatan dilakukan untuk mengetahui keadaan lingkungan sekolah dan juga pelaksanaan kegiatan pembelajaran seni budaya peserta didik di sekolah.

Esterberg (Sugiyono, 2015:25) mendefenisikan wawancara merupakan pertemuan dua orang untuk bertukar informasi dan ide malalui tanya jawab, Wawancara dimaksudkan untuk memperoleh data primer dari informan dengan bantuan pedoman wawancara. Wawancara yang dilakukan dalam penelitian ini adalah wawancara terstruktur yakni peneliti menggunakan pedoman untuk melakukan wawancara. Pedoman wawancara dilengkapai dengan pertanyaan yang sesuai dengan topik penelitian. Pedoman wawancara memuat kerangka dan garis besar pokok yang ingin ditanyakan kepada informan. Melalui wawancara data dan informasi yang diperoleh berupa deskripsi tentang pembelajaran seni budaya yang berkaitan dengan seni musik dan seni tari. Dengan wawancara ini kehilangan data yang diperlukan sangat kecil. Penelitian melakukan wawancara kepada guru kelas dan peserta didik di SDI Manunai Maumere guna memperoleh informasi yang berkenaan dengan konsep pemahaman pendididkan seni melalui pembelajaran seni budaya.

Dokumentasi yakni sejarah yang telah lewat. Baik berupa patung, lukisan dan gambar lainnya. Dokumentasi seperti sejarah seperti catatan harian, kisah kehidupan sketsa, dan lain-lain. Dokumen yang berbentuk karya misalnya karya seni, yang dapat berupa gambar, patung, flim, dan lain-lain. Teknik dokumentasi merupakan perlengkapan dari pengunaan metode observasi dan wawancara dalam penelitian kualitatif (Sugiyono 2015:33).

Dokumentasi dalam penelitian ini berupa dokumentasi foto atau sejarah misalnya mendokumentasi bentuk-bentuk lukisan yang ada di dinding kelas dan dokumentasi administrasi. Dokumentasi foto berupa foto proses pembelajaran seni budaya serta objek lain dengan hal tersebut. Sedangkan dokumen administrasi berupa pengumpulan dokumen - dokumen administratif guru dan sekolah yang berhubungan dengan pembelajaran seni budaya. 


\section{Angket}

Teknik angket digunakan bila responden jumlahnya besar dapat membaca dengan baik, dan dapat mengungkapkan hal-hal yang sifatnya rahasia (Sugiyono, 2015:21). Angket yang Peneliti menggunakan adalah angket untuk mengetahui tingkat pemahaman atau kemampuan siswa setelah mengikuti proses pembelajaran sehingga angket ini harus diisi oleh responden atau siswa itu sendiri yakni tentang pembelajaran seni budaya melalui pelajaran sosial budaya dan pekerti di SDI Manunai dengan menyebarkan angket kepada responden yaitu peserta didik kelas IV SDI Manunia Maumere untuk diisi sesuai dengan pemahaman peserta didik. Angket dalam penelitian ini tersusun menjadi 20 butir pertanyaan. Menurut Sugiyono (2015:52) skala yang digunakan dalam tes ini adalah menggunakan modifikasi skala Likert dengan interval 1 samapi dengan 4 dan 4 alternatif jawaban.

\section{Uji Coba Instrumen}

Instrumen yang telah dibuat dan disetujui akan diuji coba untuk mengetahui apakah instumen termasuk baik atau tidak. Instumen yang baik merupakan instrumen yang memenuhi syarat validitas dan reliabilitas. Instrumen yang telah dibuat akan menggunakan responden di SDI Manunai Maumere.

\section{Teknik Analisis Data}

Bogdan (Sugiyono, 2015:44) analisis data merupakan cara untuk mencari kebenaran dari hasil penelitian. Analisis Data Kualitatif. Dalam menganalisis data secara kualitatif, setelah data terkumpul baik dari data primer maupun data sekunder, peneliti menganalisis dalam bentuk deskripsi. Analisis deskripsi merupakan analisis yang dilakukan dengan memberikan gambaran dari data yang diperoleh di tempat penelitian. Analisis data dalam kualitatif lebih difokuskan selama proses di tempat penelitian sesi dengan pengumpulan data.

Analisis data sebelum di lapangan pada penelitian ini dimulai dari peneliti melakukan observasi untuk menemukan masalah yang terdapat di SDI Manunai, kemudian peneliti menganalsis masalhdi SDI Manunai, kemudian peneliti memfokuskan penelitian kepada pembelajaran seni budaya di SD pada pembelajaran sosial budaya dan pekerti di SDI Manunai. Peneliti menganalisis dengan cara reduksi, atau mengumpukan data dari berbagai sumber, baik dari 
wawancara, observasi dan dokumentasi. Penyajian atau menyajikan data setelalah di lakukan reduksi yakni memeilih data-data yang dianggap perlu itu yang disajikan oleh peneliti, dan menarik kesimpulan, penarikan kesimpulan ini dilakukan setelah melewati beberapa tahap di atas sehingga peneliti bias menyimpulkan hasil dari penelitiannya (Sugiyono, 2015:44).

\section{HASIL DAN PEMBAHASAN}

Pendidikan seni pada dasarnya berfungsi sebagai pemenuhan kebutuhan dan berekspresi, berapresiasi pada setiap anak. Seni juga sebagai media untuk mentransfer kemampuan psikomotorik pada anak dan upaya melestarikan budaya. Tujuan pembelajaran merupakan kearah mana siswa akan dibawa (Syafi'i, 2006). Tujuan seni untuk menumbuhkembangkan kemampuan psikomotik pada anak dan mampu hidup rukun dalam bermasyarakat (Syafi'i, 2006: 30). Proses belajar dan pembelajaran seni di lingkungan sekolah dapat mengembangkan kemampuan murid dalam berkarya yang bersifat visual dan rabaan. Fungsi yang didapatkan pada pembelajaran seni rupa yaitu dapat menarik minat siswa dan bias meningkatkan potensi pada anak seperti kemampuan kognitif, afek tif dan psikomotorik siswa (Kurniawati, 2011:40). Pembelajaran seni selain berfungsi untuk mendorong dan meningkatkan potensi juga berfungsi sebagai perkembangan dari aspek psikomotorik pada anak.

Selanjutnya setelah sketsa telah selesai dibuat, tahap pencampuran warna dan pemberian warna pada obyek lukisan dipraktikan. Hasil dari pengumpulan data melalui dokumentasi peneliti dapat menerangkan konsep dalam proses pembelajaran. Merryl Goldberg (dalam Retnowati, 2010 ) Sebagai contoh, peneliti memperkenalkan lukisan Piet Mondrian sebagai cara dalam proses belajar serta dengan menggunakan bantuan media atau lukisan yang sudah ada.

Belajar lewat seni dapat diimplementasikan di setiapa seklah baik di SD, SMP dan SMA bahkan perguruan tinggi. Siswa akan secara aktif dilibatkan dalam berpikir dan imajinatif dalam belajar melalui seni dan mengkonstruksi makna. Oleh karena itu pembelajaran yang dilakukan melalui seni sangat cocok bila diterapkan pada kelas IV Sekolah Dasar. Belajar yang dilakukan melalui seni daapt melibatkan kemampuan psikomotorik pada anak. Sebagai salah satu yang di 
lihat setelah melihat beberapa lukisan yang dipajang didinding kelas yang dibuat oleh guru maupun seniman yang terkenal sehingga bisa digunakan sebagai contoh oleh siswa.

Hasil penelitian ini berupa laporan hasil penelitian yang diperoleh dari proses prngamatan peran seorang guru di dalam proses pembelajaran seni budaya di SDI Manunai Maumere yang berupa catatan lapangan, lembar pengamatan peranan guru, dan dokumentasi dalam setiap pertemuan. Sebelum dilakukan penelitian terlebih dahulu dilaksanakan pra observasi atau peelitian pendahuluan. dalam pembelajaran seni budaya adalah metode drill (latihan) dan menggunakan model pembelajaran bermain peran. Metode dan model ini digunakan karena menurut beliau merupakan metode yang paling mudah bagi siswa sekolah dasar. Hasil yang didapatkan dari penelitian ini merupakan deskripsi dari observasi, wawancara,dokumentasi, dan hasil instrumen pengamatan peranan guru. Guru seni budaya di SDI Manunai Maumer di kelas IV dengan jumlah siswa 30 siswa, penelitian dilakukan sebanyak 6 kali pertemuan setiap hari Senin.

\section{Peranan Guru}

Dari sembilan peranan guru yang peneliti amati hanya lima yang akan dilaksanakan oleh seorang guru pada saat melakukan s e b u a h pertemuan pertama ini yaitu guru sebagai pembuat pembelajaran yang akan dilakukan (designer of intruction), guru sebagai penjaga pembelajaran (manager of instruction), guru sebagai pemberi petunjuk pembelajaran pada siswa, guru sebagai evaluator terhadap hasil belajar siswa (evaluator of student learning), dan yang terakhiri adalah tugas dan tanggung jawab guru untuk memfasilitasi siswa dalam pembelajaran.

Saat pertemuan ke II guru da Sembilan pertemuan guru hanya delapan yang dilaksanakan yaitu guru sebagai tukang perancang pembelajaran (designer of instruction), guru sebagai untuk pengelola pembelajaran (manager of instruction), guru sebagai member pengarahan pembelajran, guru sebagai penilai (evaluator of student learning ), guru sebagai tempat konsultasi, guru sebagai petugas kurikulum berbasis lingkungan, dan yang terakhir adalah tugas dan tanggung jawab guru. 
Dapat diketahui bahwa 9 peranan guru yang peneliti amati hanya 7 yang dilaksanakan oleh guru pada pertemuan ketiga ini. Guru sebagai perancangan pembelajaran (designer of intruction), Guru berperan sebgai pengelola pembelajaran (manager of intruction), Guru sebagai pengarah pembelajaran, perannya sebagai konselor, Guru dalam pembelajaran yang menerapkan kurukulum berbasis lingkungan, tugas dan tanggung jawab guru.

Dari sembilan peranan guru ternyata guru melaksanakan peranannya. Yaitu guru hanya sebagai perancangan pembelajaran guru sebagai pengelola pembelajaran ( Manager of Instruction), guru untuk pengarah pembelajaran, guru sebagai evaluator (evluator of Student Learning), guru untuk konselor, guru sebagai pelaksanaan kurikulum berbasis lingkungan, tugas dan tanggung jawab guru, dan yang terakhir guru yang baik dan berhasil.

Dari sembilan peranan guru yang peneliti amati hanya delapan yang dilaksanakan pada pertemuan kelima ini. Yaitu guru sebagai tukang perancangan pembelajaran guru sebagai mengelola pembelajaran (manager of instruction), guru sebagai member arahan pembelajaran, guru sebagai penilai ( evaluator of student learning), guru sebagai tempat konsultasi pada prose belajar dan pembelajaran di sekolah.

Dari sembilan peranan guru hanya enam yang dilaksanakan oleh guru pada pertemuan keenam II. Sesuai dengan pendapat Pamungkas dkk (2017) Guru dapat menjalankan perannya pada setiap pertemuan pembelajaran yaitu pada pertemuan pertama sampai pertemuan kelima, akan tetapi tidak semua peran dapat dijalankan guru pada setiap pertemuan. dijalankan oleh guru selama 5 kali pertemuan dari 13 peran guru. Guru sebagai korektor, guru sebagai informator, guru sebagai organisator.

Hasil wawancara dengan guru seni di SDI Manunai Maumere menyatakan selama ini kegiatan pembelajaran melukis di SDI Manunai Maumere lebih condong menggunakan media pembelajaran yang sederhana atau yang mudah dipahami oleh siswa yaitu contoh-contoh hasil karya lukisan yang terpajang di ruang lukis dan juga lukisan hasil karya guru yang dijadikannya sebagai bahan ajar, setelah melakukan penelitian siswa bisa melukis tanpa menggunakan media 
yang terpajang di ruang lukis yakni siswa bias berimajinasi sehingga bias menghasilkan sebuah lukisan yang baru.

Sedangkan hasil angket yang disebarkan kepada siswa dapat disimpulkan bahwa $80 \%$ peserta didik menyatakan bisa membuat lukisan secara langsung dan tidak perlu menggunakan media secara langsung ataupun lukisan-lukisan yang terpajang di dinding kelas. Sesuai dengan penelitian yang dilakukan oleh Kusumastuti (2014) Model pembelajaran seni tari terpadu ini dilakukan dengan berurutan secara terpadu dengan menggunakan pendekatan ekspresi bebas, disiplin ilmu dan multikultural. Setiap pokok bahasan bisa dijelaskan dengan menggunakan ketiga pendekatan secara berurutan atau bersamaan.

Cara Guru Memilih Media Pembelajaran yang efektif memerlukan perencanaan yang baik. Media yang akan digunakan dalam proses pembelajaran itu juga memerlukan perencanaan yang baik. Dalam hal ini, guru pembina memilih media dengan mempertimbangkan beberapa aspek, diantaranya adalah: menyesuaikan dengan kompetensi atau tujuan dan kesesuaian dengan materi. Sesuai dengan yang dipaparkan Arsyad (2009:22), "kriteria cara untuk memilih media pemilihan berasal dari konsep bahwa media merupakan bagian dari sistem instruksional secara keseluruhan. Fungsi media adalah untuk menyampaikan pesan yang diberikan oleh guru kepada siswa. Karaktristik media yg baik pada saat pembelajaran yaitu media yang sesuia dengan materi yang kan dibahas supaya tujuan pemebelajaran bisa tercapai.

Selain tercapai juga tepat untuk mendukung isi pelajaran yang sifatnya fakta, konsep, prinsip atau generalisasi; praktis, luwes dan bertahan; guru terampil menggunakannya; pengelompokan sasaran; dan mutu teknis. Guru memilih kriteria sesuai dengan tujuan yang ingin dicapai dan tepat untuk mendukung isi pelajaran yang sifatnya fakta, konsep atau generalisasi. Media yang akan dipilih sesuai tujuan yang telah ditetapkan dan secara umum mengacu pada tiga ranah keampuan, sikap, dan keterampilan. Tujuan ini hanya dapat digambarkan dalam bentuk tugas yang harus dikerjakan atau ditunjukkan oleh siswa, seperti menghafal apa yg ditugaskan oleh guru, melakukan berbagai macam kegiatan kegiatan yang melibatkan kegiatan fisik atau non pisik. 
Sedangkan untuk kriteria kesesuaian dengan materi yaitu media dipilih secara tepat untuk mendukung proses pelajaran yang fakta, konsep, prinsip, dan generalisasi. Media yang sangat berbeda, misalnya film atau grafik memerlukan kode yang sangat berbeda, karena itu memerlukan proses dan keterampilan siswa yang berbeda untuk mengerti. Agar dapat membantu berjalannya proses pembelajaran secara baik, media harus sesuai dengan topik yang dibahas supaya hasil yang didaptkan bias maksimal dan sesuai dengan kebutuhan tugas pembelajaran dan kemampuan mental peserta didik. Cara yang digunakan oleh guru untuk melakukan pemilihan media pembelajaran harus yang sederhana yang mudah dipahami oleh siswa pada saat digunakan. Oleh karena itu, guru kelas harus memilih media pembelajaran yang cepat dipahami oleh siswa supaya mudah dimengerti oleh peserta didik seperti lukisan-lukisan para pendahulunya yang di taruh di kelas dan juga lukisan yang dibuat oleh guru yang lain.

Cara Guru dalam Penggunaan Media Pembelajaran Berdasarkan hasil penelitian di lapangan, menjelaskan bahwa kegiatan pembelajaran melukis di SDI Manunai Maumere lebih condong menggunakan media pembelajaran yang sederhana yaitu contoh-contoh hasil karya lukisan yang terpajang di ruang lukis dan juga lukisan hasil karya guru yang dijadikannya sebagai bahan ajar. Hal ini tentunya tidak dapat disamakan dengan media teknologi pendidikan, sebab antara media pembelajaran dan media teknologi pendidikan mempunyai pengertian yang berbeda. Dalam buku Arsyad (2009:5), menurut Webster "art" adalah psikomotorik (skill) yang didapatkan lewat pengalaman, studi dan observasi. Dengan demikian, teknologi tidak lebih dari suatu ilmu yang membahas tentang keterampilan yang diperoleh lewat pengalaman, studi, dan observasi melainkan dari aspek kognitif dan afektif.

Dari kondisi di lapangan bahwa guru menggunakan pilihan media tradisional (Visual yang tak diproyeksikan), yaitu guru memperlihatkan hasil lukisan yang terpajang di kelas, selain itu guru pembina juga membuat lukisan yang dijadikannya sebagai bahan ajar supaya menarik perhatian siswa untuk berkarya lebih baik.Sesuai dengan yang dipaparkan Arsyad (2009), "Salah satu ciri media pembelajaran adalah bahwa media mengandung dan membawa pesan 
atau informasi kepada penerima yaitu siswa. Sebagian media dapat mengolah pesan dan respons siswa sehingga media itu sering disebut media interaktif'

Pelaksanaan kegiatan pembelajaran materi seni lukis. Kegiatan yang dilakukan oleh guru dan siswa adalah sebagai berikut:Kegiatan awal yang dilakukan oleh guru pembina adalah membuka pelajaran dengan menggunakan media pembelajaran yaitu memberi salam dan membuka kegiatan dengan doa, membahas sekilas materi yang akan diajarkan, menunjukkan contoh-contoh hasil karya yang akan diajarkan, dan memberi peneguhan tentang manfaat materi pembelajaran yang akan diajarkan untuk menyongsong masa depan. Kemudian siswa dibentuk menjadi beberapa kelompok untuk membuat karya.Guru pembina mengarahkan kepada seluruh siswa untuk membuat karya lukis sesuai dengan ide kreatif yang dimiliki oleh masing-masing kelompok, karena untuk menumbuhkan minat siswa menghasilkan karya yang beragam jenis objek dan gaya lukisannya. Seperti yang dipaparkan oleh Sachari (2007) "Objek dan gaya lukisan sangatlah beragam". Karya yang akan dibuat memerlukan ide kreatif dan inspirasi yang baik untuk menghasilkan karya yang baik pula. Setelah ide didapat, maka barulah dapat membuat sketsa dari rancangan lukisan yang akan dituangkan ke dalam bentuk lukisan.Tahap penyelesaiannya yaitu dengan pewarnaan.

Sugiyanto (2004:16), "Warna merupakan unsur rupa yang terbuat dari pigmen (zat warna)". Dalam teknik pewarnaan ini, siswa tidak dituntut untuk mewarnai lukisannya sesuai dengan penjelasan guru tersebut, melainkan dengan menggunakan daya imajinasi yang dimiliki oleh siswa, yaitu siswa bisa menggunakan berbagai media dan teknik melukis sesuai dengan kretifitas yang dimiliki oleh masing-masing siswa. Akhir dari kegiatan ini adalah denganmenutup pelajaran. Guru membuat kesimpulan mengenai materi melukis yang telah dilaksanakan dengan memberitahukan tentang hasil karya siswa yang belum selesai pewarnaannya bisa diselesaikan di rumah serta memberitahukan apa saja yang akan dibawa pada pertemuan berikutnya dan mengucapkan salam.

Kegiatan awal guru membuka pelajaran, membahas sekilas mengenai materi yang akan diajarkan, menunjukkan contoh-contoh hasil karya yang akan diajarkan. Dalam hal ini, guru memanfaatkan pengetahuan yang dimiliki oleh siswa sebagai usaha oleh Djamarah \& Zain (2006), “pengetahuan anak tersebut 
dapat dimanfaatkan untuk memancing perhatian anak terhadap bahan pelajaran yang akan diberikan, sehingga anak terpancing untuk memperhatikan penjelasan guru". Dalam mengajar, guru menggunakan variasi dalam mengajar, yaitu

Intonasi suara guru yang tidak monoton, dan juga gerakan tubuh guru ketika mengajar. Intonasi suara yang dikeluarkan guru terkadang keras dengan maksud supaya siswa memperhatikan penjelasan yang diberikan. Sedangkan gerakan tubuh ditunjukkan dengan tempat guru mengajar yang tidak di satu tempat, melainkan berpindah-pindah berselang beberapa waktu. Sesuai yang dipaparkan oleh Djamarah \& Zain (2006), “Gerakan tubuh merupakan penguatan yang dapat membangkitkan gairah belajar anak didik, sehingga proses belajar mengajar lebih menyenangkan”. Dibutuhkan interaksi antara guru dan siswa untuk membuat proses pembelajaran dapat berlangsung dengan baik. Oleh sebab itu, ketika guru menjelaskan materi, seringkali guru menanyakan kesulitan belajar yang dialami oleh siswa atau tidak. Hal ini dengan maksud supaya tujuan pembelajaran dapat berjalan dengan baik. Sesuai dengan yang dipaparkan oleh Djamarah \& Zain (2006), "Hal ini terjadi karena interaksi yang terjadi antara guru dengan anak didik seiring untuk mencapai tujuan pengajar

\section{SIMPULAN}

Berdasarkan hasil pengamatan peranan guru dapat disimpulkan beberapa hal yang berkaitan dengan peranan guru dalam pembelajaran seni budaya di SDI Manunai Maumere Guru dapat menjalankan peranannya pada setiap pertemuan pembelajaran yaitu siswa bisa melukis tanpa menggunakan media yang disekitar siswa. pada pertemuan pertama sampai dengan pertemuan keenam, akan tetapi tidak semua peranan dapat dilaksanakan guru pada setiap pertemuan. Terdapat tujuh peranan yang dilaksanakan oleh guru selama enam kali pertemuan. guru sebagai pembuat pembelajaran sebagai pengelola atau penjaga pembelajaran Guru sebagai pengarah atau member petunjuk pembelajaran langsung kepada siswa, guru sebagai penilai (Evaluator of Student Learning), guru sebagai tempat konsultasi bagi siswa, dan guru bisa dapat merespon kekurangan yang dialami oleh siswasiswa pada saat proses belajar dan mengajar, guru sudah berperan dalam pembelajaran yang menerapkan kurikulum berbasis lingkungan di sekolah 


\section{DAFTAR PUSTAKA}

Abdi. 2006. Seni Budaya. Demak: Erlangga.

Arsyad \& Azhar. 2009. Media Pembelajaran. Jakarta: Raja Grafindo Persada.

Djamarah \& Zain. 2006. Pembelajaran bidang seni di sekolah dasar. Bogor:PT Bumi Aksara.

Hamalik \& Oemar. 2011. Kurikulum dan pembelajaran. Jakarta: PT Bumi Aksara.

Hosnan, M. 2014. Pendekatan Saintifik dan Kontekstual Dalam Pembelajaran Abad 21. Bogor: Ghalia Indonesia.

Moh. Usman. U, 2013. Menjadi Guru Profesional. Bandung: Remaja Rosdakarya.

Majid, A. 2014. Strategi Pembelajaran. Bandung: PT Remaja Posdakarya.

Mustika \& Wayan. 2013. Teknik Dasar Gerak Tari Lampung. Banda Lampung: Anugrah Utama.

Munandar U. 1985. Mengembangkan Bakat dan Kreativitas Anak Sekolah, Jakarta: Gramedia.

Narbuko, Cholid \& Achmadi, Abu. H 2012. Metodologi Penelitian. Jakarta: PT Bumi Aksara.

Ngalim \& Purwanto. 1995. Ilmu Pendidikan Teoritis dan Praktis, Bandung: Rosda.

Karya, Prastowo, \& Andi. 2013. Pengembangan Bahan Ajar Tematik. Jogjakarta : DIVA Press.

Kusumastuti, E. (2014). Penerapan Model Pembelajaran Seni Tari Terpadu pada Siswa Sekolah Dasar. Jurnal mimbar sekolah dasar. Vol. 1, No. 1.

Kurniawati, Dwi W. (2011). Pembelajaran Seni Rupa Di SD: Studi Eksploratif Pemanfaatan Grajen Warna Sebagai Media Pengembangan Kreatuvitas dalam Berkarya Seni Membentuk Bagi Siswa Kelas 5 SDN Jepon 2 Blora. Skripsi. UNNES. Semarang.

Pamungkas. R., Wendhaningsih. S,. \& Hasyimkan. (2017). Peran Guru Dalam Pembelajaran Seni Tari SMAN 1 Seputih Agung Lampung Tengah. Jurnal Seni dan Pembelajaran. UNILA

Pusparini, D. (2016). Analisis Peran Guru dalam Pembelajaran Seni Musik di Sekolah Dasar Sekbin III Kecamatan Brebes Kabupaten Brebes. Under graduates thesis, universitas negeri semarang. 
Rusman. 2012. Model-model pembelajaran. Jakarta: PT Rajagrafindo Persada.

Sardiman. 2012. Interaksi motivasi dan Belajar Mengajar. Jakarta: PT Rajagrafindo Persada.

Sriwirasto. 2010. Mari Melukis. Jakarta: PT. Elex Media Komputindo.

Satori, D \& Komariah, A. 2013. Metodologi penelitian kualitatif. Bandung: PT Alafabeta.

Retnowati, H \& Prihadi, B. 2010. Modul Pembelajaran Seni Rupa. http://staff.uny.ac.id.pdf.

Syafii. 2006. “Konsep Pembelajaran Seni Rupa”. Hand Out. Sema- rang: Unnes Press.

Soehardjo. 2012. Pendidikan Seni: Dari Konsep Sampai Program. Malang: Bayu Media Publishing.

Sugiyono. 2015. Metode Penelitian Kuantitatif Kualitatif dan $R \& D$. Bandung: PT Alafabeta.

Sugiyono. 2013. Metode Penelitian Kuantitatif Kualitatif dan $R \& D$. Bandung: PT Alafabeta.

Sugiyono. 2012. Metode Penelitian Pendidikan. Bandung: PT Alafabeta.

Sumanto. 2006. Pembelajaran Seni di Sekolah. Jakarta: Bumi Aksara.

Hamzah. U. B. 2012. Profesi Kependidikan. Jakarta: PT Bumi Aksara. 